\title{
Heritage as image of the nation
}

The symbolic use of heritage played a crucial role in Ethiopian domestic and international political communication. Visual representations of a strong Ethiopia, embarking into modernity on the foundations of a past that was referred to as the "Great Tradition", were used to create and promote an image of Ethiopia as a modern country with international reach and impact. The historiographical framework of this Great tradition was the state nationalism of the Ethiopian monarchy and was actuated in the late nineteenth and the first half of the twentieth century, to support and legitimise centralisation, imperial expansion and modernisation of the Ethiopian nation-state. It centres around the legendary biblical encounter of King Solomon and the Queen of Sheba, and the relocation of the Arc of the Covenant from Jerusalem to Aksum through their son in the aftermath of the encounter. Documented in writing for the first time in the fourteenth century, this mythology explained the foundation of the Ethiopian monarchy and positions Ethiopia as the new Zion and Ethiopians as the new chosen people of God. The Ethiopian exceptionalism narrated in this mythology ascertained the lineage of the monarchic rule and explained racial differences between highand lowland population and between Christian centres and non-Christian peripheries within Ethiopian state territory. Alongside the "teleological unfolding of such monarchy-centred and divinely orientated history" as the foundation for an Ethiopian national identity, monarchy was presented as the "moulder and the guarantor of this identity". ${ }^{172}$

\section{Establishing images of Ethiopian exceptionalism during the 1960 s and 1970 s}

The Great tradition played a central role in how the Ethiopian nation was imagined and articulated by political and intellectual actors, and by outsiders. Elisabeth Wolde Giorgis has argued that Dipesh Chakrabarthy's assumption of a myth that performs as an objective truth and that functions as an imaginary bonding between nation and citizen applies to the analysis of Ethiopian nationalism, too.

Applying a more complicated approach of Benedict Anderson's category of "imagination", she makes a point that "In Ethiopia, the unifying ideology of nationhood between the rulers and the masses was a successful strategy that de-

172 Marzagora, "History", 6; see also Wendy Laura Belcher, "From Sheba They Come: Medieval Ethiopian Myth, US Newspapers, and a Modern American Narrative”, Callaloo 33, no. 1 (2010): $239-57$.

Ә OpenAccess. () 2021 Marie Huber, published by De Gruyter. (cc) BY This work is licensed under the Creative Commons Attribution 4.0 International. https://doi.org/10.1515/9783110681017-005 
fined the ways the nation was presented not only as the primary source of loyalty and solidarity, but also as the rallying image in the discourse of modernity." The historical imaginary derived from the Great tradition was central in how Ethiopian modernity was narrated and was the social base of Ethiopia's modern nation building. While for a long time the biblical myth of Christian highland enclave was the core of this imaginary, the sensational paleontological discoveries extended this exceptionalism further to the very beginnings of human life on earth. ${ }^{174}$

Several scholars have recently analysed the intellectual history of the Ethiopian national imagination in scholarship and literature, responding to increasing critical perspectives from a number of renowned senior scholars on historiographical practices in Ethiopia and Ethiopian historical studies. ${ }^{175}$ They have delivered very thorough analysis of written works by Ethiopians. Yet, their analysis doesn't go deeper into the influence of the Western view of Ethiopian culture and history and the abundant image-production related to the Great tradition. Government publications from various sectors and levels utilised photographs and drawings to illustrate the Ethiopian nation and constructed distinct visual imaginaries of Ethiopian past, present and future. Ancient monuments, natural scenery and wildlife featured very prominently in this image production.

From the 1950s on, images of heritage were part and parcel of governments' communication strategy and in line with Haile Selassie I's extensive use of media to create an iconography and image-cult of his leadership. The selected visual representation of heritage as national monuments turned into an iconography of national success in its own right. ${ }^{176}$ When Ethiopia intensified its efforts to obtain technical assistance and development funds, beginning with the first Ethiopian five-year development plan in 1959, the Ethiopian government started

173 Elizabeth Wolde Giorgis, “Charting out Ethiopian Modernity and Modernism”, Callaloo 33, no. 1 (2010): 85 .

174 Izabela Orlowska, "Forging a Nation: The Ethiopian Millennium Celebration and the Multiethnic State”, Nations and Nationalism 19, no. 2 (2013): 304-5, https://doi.org/10.1111/nana. 12021.

175 Marzagora, "History”; Triulzi, "Battling with the Past"; James de Lorenzi, Guardians of the Tradition: Historians and Historical Writing in Ethiopia and Eritrea (Rochester, NY: University of Rochester Press, 2015).

176 Jeylan Wolyie Hussein, "The Subtle Connection between the Greater Ethiopia Image, the Ideology of Blaming and Silencing, and the Cult of Emperor Haile Selassie”, The Australasian Review of African Studies 27, no. 1 (2005): 63-64; John Gartley, "Control of Media and Concept of Image by Haile Selassie I", in Études éthiopiennes: Actes de la Xe conférence internationale des études éthiopiennes, Paris, 24-28 août 1988, ed. Claude Lepage, vol. 1 (Paris: Société française pour les études éthiopiennes, 1994), 653. 
to produce publications to present and advertise investment opportunities internationally. In this context, Ethiopian history, heritage sites and monuments gained relevance as national brand icons, and were used to illustrate and symbolise Ethiopia's continuity as a form of proof of the high potential there for success and development.

The book Economic Progress of Ethiopia was published in 1955 as part of the imperial Silver Jubilee commemorations by the Ministry of Commerce and Industry. It was "intended as an outline of some aspects of the massive progress [...] during the twenty-five years of the inspired reign of His Imperial Majesty Haile Selassie I". ${ }^{177}$ In a collection of short articles the sectoral development of financial, agricultural, health, education and communication affairs in Ethiopia between ca. 1925 and 1950 was described, and supported by more than eighty pages of detailed statistics regarding these matters. On the book's cover, the title was embossed in gold, together with a drawing of the large Aksum Obelisk. On the first page, the same obelisk is portrayed as a black-and-white drawing, with the surrounding scenery in Aksum, including other monuments, trees and people. The detailed observations of the more recent past were connected in the ancient past of the Aksumite empire, locating the modernisation and progress underway in Ethiopia on a historical trajectory.

Promotional material, whose principal aim it was to convey the idea of economic success and successful development to a worldwide audience, frequently came adorned, illustrated with images of heritage sites. As an example, see Patterns of Progress - Ethiopia - Past and Present, ${ }^{178}$ published in 1967 under the auspices of the Ethiopian Ministry of Information. Starting with a biographical overview of Haile Selassie I's life and an anchoring of Ethiopian history in antiquity, the modern government and its achievements in various sectors are then presented, illustrated with images of modern machinery, spotless urban scenes of modern Addis Ababa and neatly dressed people. As will be shown, the images in these government publications circulated widely through diplomatic relations and international networks. The image production of the tourism promotion, built around the same core-portfolio of monumental heritage and highland scenery, intensified this circulation.

In the official representation of the socialist government, the Abyssinian, north-Ethiopian culture was still central. Many representatives of the Amharic elites who had shaped cultural politics of the imperial government continued

177 Ethiopia, ed., Economic Progress of Ethiopia (Addis Ababa, 1955), vii.

178 Ministry of Information, ed., Ethiopia, Past and Present, Patterns of Progress 8 (Addis Ababa: Publications \& Foreign Languages Press Department; Ministry of Information, 1967). 
in their functions and maintained their status as elite heritage-makers after the revolution. In publications like the book Ethiopia-a decade of revolutionary transformation, published in 1984 by the Ministry of Information, the country's history was utilised as a lead-up to the glorious revolutionary present, spread out over six pages and with photos of the most prominent heritage sites. The introductory section concluded with a paragraph arguing the revolution to be the historical moment of fulfilling "the determination of the Ethiopian people to defend freedom, independence, human dignity and justice”, which had been denied them by the old system. ${ }^{179}$

Heritage as a political asset took on a prominent role in foreign policy and diplomacy. The monumental heritage functioned as a form of social as well as cultural capital that underpinned Ethiopia's claim to international recognition and appreciation. The Ethiopian government aimed to maintain and expand the image of a strong country in order to stabilise political power and enable foreign investment. According to the elite historiography of the "Great Tradition" of the Ethiopian empire, Ethiopia was the most advanced civilisation in Africa, an idea that played an important role in the regional positioning of Ethiopia and beyond.

Ethiopia's resistance against colonial occupation was firmly woven into the larger narrative of the "Great Tradition", of a strong, continuous and ancient empire which was naturally the leader of African states and therefore a key partner for the United Nations and the West. In the context of the Pan-African movement during the 1960s, this image of Ethiopia as Africa's oldest empire became especially relevant, and promoting it formed a central element in Haile Selassie I's foreign policy. In order to strengthen his domestic position, Haile Selassie I placed a particular emphasis on international relations in his politics. His international political strategy was twofold and combined a repositioning of Ethiopia within the African continent and the Organisation of African Unity (OAU), as well as on the international diplomatic stage of the UN. Images of the classic monumental cultural heritage sites were employed in rhetoric and visual representation to support these political strategies to an international audience of politicians and diplomats.

Haile Selassie's achievement of succeeding against the Italian occupation, without undergoing a longer existence as a colony, had turned Ethiopia into an aspirational symbol for the independence struggles of other African countries

179 Propaganda and Culture Committee of the Founding Congress of the Workers' Party of Ethiopia \& 10th Anniversary of the Revolution, ed., Ethiopia: A Decade of Revolutionary Transformation, 1974-1984 (Addis Ababa: the committee, 1984), 17. 


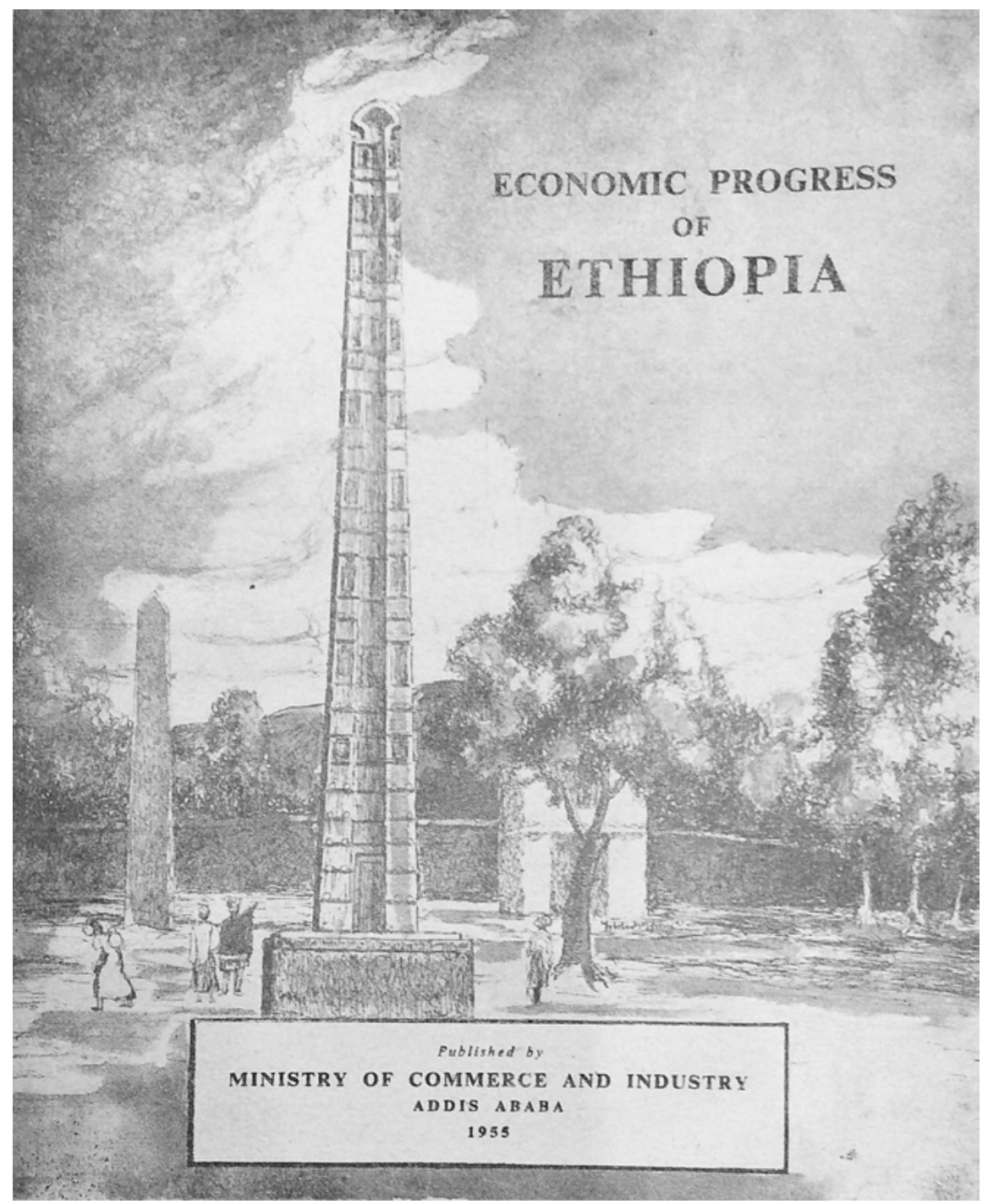

Figure 3: Cover image, Ethiopia, ed. Economic Progress of Ethiopia. Addis Ababa, 1955.

in the 1950s and 1960s. Political leaders of nationalist movements referred to Haile Selassie I's Ethiopia as an important role model for resistance against colonial oppression, and many of them also expressed their respect for "the one great African kingdom which, except for a single tragic interlude which only enhanced his claim, had stood through two millenia [sic] and had shone, at least to 
the intelligentsia, as a beacon of independence and African civilization [sic] to the rest of a continent held in subjection to Europe."180

Ethiopian intellectual elites identified readily with this description delivered by the British Historian Margery Perham in her 1969 book on the Ethiopian government and displayed "pride in their own history and cultural heritage which had not been rendered inferior by a prolonged European colonial presence" 181 .

During the 1950s and 1960s, the glorification of Ethiopian history by African nationalist movements shifted the Ethiopian self-perception of not belonging to Africa. ${ }^{182}$ At the same time, Ethiopia started to open up and to orientate politically towards the African continent. The Ethiopian political position claimed superiority in the process of the re-formation of the African continent as a political entity through reference to a particular Ethiopian national heritage. Haile Selassie I strategically engaged in the role of African leader awarded to him by the leaders of national liberation movements of African states, and used this role to strengthen his political power. He directed, at least in an African context, his external politics towards an understanding "that the Ethiopian people belong to the coloured nations of Africa" and Ethiopia was "a connecting link between Africa and Europe." ${ }^{183}$ Early on, he received leaders of African independence movements as official state guests, and provided support to political refugees. During the peak of decolonisation from around 1960, the Pan-African idea had experienced a decisive shift from a discourse largely located in the African diaspora to an applied movement on the ground that became ever more prominent and relevant as a political concept. ${ }^{184}$ The foundation of the OAU seemed to materialise this vision of a continental unity that would aid in overcoming the damages caused by colonial rule and develop competitive strength

180 Margery Perham, The Government of Ethiopia, 2nd ed. (London: Faber \& Faber, 1969), lix. 181 Randi Rønning Balsvik, Haile Selassie’s Students: The Intellectual and Social Background to Revolution, 1952-1977 (Addis Ababa; East Lansing, MI: Addis Ababa University Press; African Studies Center, Michigan State University, in cooperation with the Norwegian Council of Science and the Humanities, 2005), 209.

182 Balsvik, 206-7; Perham, The Government of Ethiopia, 1-li.

183 Mission report, no date, in: UNESCO 008 (63) MP 03.

184 Also the emergence of the Rastafari movement in connection with the prophetic statements of Marcus Garvey's black nationalism was based on a version of the "Greater Ethiopia” image: the image of "Ethiopia as a sacred sovereign", Giulia Bonacci, "From Pan-Africanism to Rastafari: African American and Caribbean "Returns" to Ethiopia", in Understanding Contemporary Ethiopia: Monarchy, Revolution and the Legacy of Meles Zenawi, ed. Gérard Prunier and Éloi Ficquet (London: Hurst, 2015), 151. 
on an international level. ${ }^{185}$ Yet the process of African unification was challenged by a political division between more radical democratic demands and more conservative positions, resulting in the formation of different groups in pursuit of African unity. From an Ethiopian point of view, demanding the maintenance of national sovereignty for the newly created African states worked in favour of Ethiopian geopolitical interest, especially when the sanctity of colonial borders was invoked during the dispute over the Ogaden region. Through diplomatic efforts, Haile Selassie I eventually secured a position in which the Ethiopian approach would seem to represent the interest of the majority of the newly independent African states, overruling ideas of a continental integration, a continental government and any redrawing of boundaries. ${ }^{186}$ Haile Selassie I's strategy included the installation of the headquarters of the OAU in Addis Ababa, officially promoting Ethiopia, and more specifically Addis Ababa, to the centre of interAfrican diplomacy. ${ }^{187}$

The installation of the OAU headquarters in Addis Ababa was part of a larger strategy by the Ethiopian government to establish Addis Ababa as a major location for African and international political conferences, and as a diplomatic hub. The Ethiopian government was able to provide a sufficiently independent infrastructure, including conference and office buildings, high-end hotels and the well-connected services of EAL. Furthermore, the image of Ethiopia as an African leader and the only stable African country played to the advantage of Haile Selassie I, who acted as spokesman for Africa on the international stage and managed in 1958 to secure Addis Ababa as the site for UNECA. UNECA, as well as several other UN agencies, could be conveniently housed in the newly built Africa Hall, a modern, representative building, provided at the cost of the Ethiopi-

185 Andreas Eckert, "Bringing the "Black Atlantic" into Global History: The Project of Pan-Africanism", in Competing Visions of World Order: Global Moments and Movements, 1880s-1930, ed. Sebastian Conrad and Dominic Sachsenmaier (New York: Palgrave Macmillan, 2007), 240 - 42; Peter O. Esedebe, Pan-Africanism: The Idea and Movement, 1776-1963 (Washington, D.C.: Howard University Press, 1982), ix; Asfa-Wossen Asserate, Der letzte Kaiser von Afrika: Triumph und Tragödie des Haile Selassie (Berlin: Propyläen-Verlag, 2014), 291-99.

186 Ethiopia had a keen interest in opposing the strongest opponent of withdrawal, Somalia, as this would have cost Ethiopia some territory in the south, which, while populated mostly by Somalis, did have the prospect of oil reserves. Dereje Feyissa and Markus Virgil Hoehne, "One State Borders and Borderlands as Resources: An Analytical Framework”, in Borders and Borderlands as Resources in the Horn of Africa, ed. Dereje Feyissa and Markus Virgil Hoehne (Woodbridge: Boydell \& Brewer, 2010), 4-5; John Markakis, Resource Conflict in the Horn of Africa (London: SAGE, 1998), 54.

187 Christopher S. Clapham, Transformation and Continuity in Revolutionary Ethiopia (Cambridge: Cambridge University Press, 1988), 222. 
an government. ${ }^{188}$ Events such as the hosting of the UNESCO conference on education in African states in Addis Ababa in 1961 demonstrated the capacities that the Ethiopian government claimed for the country, and that others readily projected onto it. ${ }^{189}$ In all these efforts, the representation of Ethiopia as a strong country on the diplomatic and the international stage was connected to the narrative of the "Great Tradition", enriched by the defeat of colonial rule as further proof of Ethiopian "Greatness”.

\section{The foreign image of Ethiopia}

The construction of an image of the Ethiopian nation through images of heritage was influenced from the Western image of Ethiopian heritage as well. From the 1920s on, a shift in Ethiopian historiography emphasised the Ethiopian tradition as a unique and independent development, sharing roots with Western civilisations in ancient empires, scripture and Christianity. This historic exceptionalism was connected to a narrative that Ethiopian elites had cultivated for centuries and actualised with Western racist concepts and a distinct notion of not belonging, culturally speaking, to Africa. Ethiopian highland elites and Western diplomats alike did not consider Ethiopians as African. They believed that the larger part of Ethiopia had cultivated an atmosphere of a "splendid isolation", politically as well as culturally, to protect the Christian tradition against uncivilised influences from the African continent. These existing traditional racist prejudices towards the supposedly more "Negroid" population of the rest of Africa resonated with popular Western concepts of African inferiority. When Ethiopian political relations were re-routed to the European metropolises of the colonial empires during the nineteenth century, intellectual orientation, as a consequence, shifted towards Europe as well. In education and historiography, African affiliation was played down and Ethiopian history was instead rewritten in universal categories that allowed for an easier connection to the history of Western, Eurocentric civilisation. ${ }^{190}$

188 R.K.P.P., “The Economic Commission for Africa”, Ethiopia Observer VII, no. 2 (1963): 99. 189 United Nations Economic Commission for Africa, "Conference of African States on the Development of Education in Africa, Final Report” (Addis Ababa, May 15, 1961), v, https://unesdoc. unesco.org/ark:/48223/pf0000077416.locale=en.

190 de Lorenzi, Guardians of the Tradition, 63-65; Perham, The Government of Ethiopia, xlix; Robin M. Derricourt, Inventing Africa: History, Archeology and Ideas (London; New York: Pluto Press, 2011), 105-6. 
It is worth drawing attention to the image of Ethiopia held by international and development workers. In a fortunate amalgamation of Ethiopian historiography and heritage practice with Western representations and projections a specific image of Ethiopia was constructed, one that presented Ethiopia as Africa's only non-African country, endowed with civilisation, and therefore history and heritage as opposed to just folkloristic art. This image allowed for the perfect matching of selected Ethiopian heritage sites with the markers of authenticity for heritage as defined by Western experts when knowledge about Ethiopian cultural and natural heritage started to circulate through the expanding international networks. Publishing activities in particular, facilitated through UNESCO, contributed to the broad reach of the international heritage-expert's work.

Ethiopia's cultural heritage, per the mediation of UNESCO, raised favourable awareness in the broader public and was featured prominently several times in UNESCO publications. The sudden increase of photographic images relating to Ethiopia in these publications is particularly noteworthy. Not only were UNESCO's publications in the Courier or in scientific organs relevant to the promotion of the new image of Ethiopia to a Western intellectual public, but there was also a broader range of publications from experts or those declared to be such. ${ }^{191}$ This was an extensive pool that reached beyond the sphere of conservation specialists that included diplomats, entrepreneurs, travellers and researchers alike, all of which communicated their findings and observations to each other, institutions, governments and the general public. The emerging fields of cultural and natural tourism, as well as the travel and exploration activities of foreign experts posted in Ethiopia, resulted in a growing number of publications and reports during the 1960s and 1970s. The most important common feature in these reports of Ethiopia was the presentation of a non-African, ancient empire. In this narrative, emphasis was placed on Ethiopia being a culture with non-African and Christian roots. This was employed to explain Ethiopian culture's quality as a civilisation, to which one could ascribe a certain superiority and even supremacy.

The UNESCO Courier featured articles about Ethiopia on several occasions between 1959 and 1967, all of which focused on Ethiopian antiquity and its historical exceptionalism. In 1959, an article titled “The Greatness of Ethiopia” lauded the geographical features of Ethiopia which "call to mind some of Europe's mountains rather than Africa”, further explaining that the Ethiopian people had a unifying kinship to the white race "despite their dark skins" with the result "that long ago a civilisation grew up which distinguishes Ethiopia from the Negro-inhabited parts of Africa, by which it is largely surrounded, and which

191 More generally about the Courier: Maurel, Histoire de l'UNESCO, 159-60. 
gives to the country affinities with the lands of ancient civilisation-Egypt, Syria and Arabia”. ${ }^{192}$ The article continues in praise of the substantive age of Ethiopian civilisation, as well as the high stage of development and uninterrupted, untouched continuous preservation, correlating these to Arabian provenance and firm Christian belief. In addition, images of the Aksum Obelisks are featured on the first page of the magazine, declaring Ethiopian history to be "one of the most intriguing chapters in African history". ${ }^{193}$ Although this entire Courier issue dedicated to "Africa's Lost Past” was not short of articles about other African kingdoms and civilisations, written in the context of the endeavour of the African History project, the article on Ethiopia stood out because it insisted on the continuity of empire as opposed to the "lost", "unknown" or "forgotten" ones of other African countries. Ethiopia was distinguished because, in the eyes of the editors and writers of this Courier issue-as opposed to the rest of the African continent-its degree of civilisation had supposedly allowed it to remain in charge of its own history.

In 1961 UNESCO published a volume on Ethiopian manuscript paintings in the UNESCO World Art Series (UWAS). ${ }^{194}$ What is striking about this album is the attitude of discovery in which it is made, which rings familiar with typical Western representations of non-Western cultures. Initially, WHO's maternal health specialist, the German Otto Jäger, stationed in Ethiopia from around 1958 onwards, turned to UNESCO after having seen some ancient manuscripts while traveling in the northern region around Gondar in a private capacity. He suggested to UNESCO that they should attend to them. ${ }^{195}$ Jäger, together with the editor of the UWAS Peter Bellew, and an Italian photographer, undertook a tour of several weeks to gather the necessary material. The correspondence running in parallel to the production of the book reveals a strong sense of adventurism and entitlement, and an ostensible "us" and "them" perspective on Ethiopian people. Even the more distinguished research experts who were commissioned to write introductory essays for the volume reciprocated their explicit remarking of their "discovery" of the manuscript paintings on several occasions. $^{196}$

192 Jean Doresse, “The Greatness of Ethiopia”, UNESCO Courier 12, no. 10 (October 1959): 30. 193 N.N., "Giant Obelisk of Ancient Ethiopia”, UNESCO Courier 12, no. 10 (October 1959): 2. 194 Jules Leroy, Otto A. Jäger, and Stephen G. Wright, Ethiopia: Illuminated Manuscripts (Greenwich, CT: New York Graphic Society, 1961).

195 Letter from Otto Jäger, no date, in: UNESCO 7 UWAS (63).

196 Project correspondence, in particular between Stephen Wright and Peter Bellew, in: UNESCO 7 UWAS (63). 
Upon on publication of the completed volume, the Courier dedicated an article to the topic, written by Abbé Jules Leroy, author of one of the book's introductory essays and former director of the "Institut éthiopien d'études et de recherches" (in the following: "Institut"). Again, the article emphasised the unique qualities of Ethiopian civilisation: "Here, at an elevation of seven to thirteen thousand feet, was created and developed a civilisation which, from the point of view of political and cultural achievement and from that of the artistic monuments which record its long history, has no parallel in all Tropical Africa."197

This article, while generally similar in tone and ideas to the 1959 one, once again explained the concept of a "non-Negroid" race, continuous advanced civilisation and a stronger link to the Arabian Peninsula than to Africa. Additionally, Leroy insisted very strongly that only through Christianity had a "flowering of art”, on par with that of the Byzantine world, arrived and developed in Ethiopia. ${ }^{198}$ Otto Jäger, who was criticised by the others involved in the book's production for his unsound interpretation of the Ethiopian manuscript paintings, ${ }^{199}$ was nonetheless allowed to pen his own article on the paintings three years later in 1964 in the Courier, and was referred to as "author of several works on Ethiopian painting". ${ }^{200}$ In a tone of popular science, he focused on art as a "folk tradition" and his article was devoid of the term "civilisation". However, he insisted on the continuity and greatness of the culture, and for illustration he chose photos of contemporary Ethiopia resembling scenes from the old paintings, such as religious procedures and clothing habits, aiming to depict a lifestyle of the Ethiopian people that had remained unchanged throughout the centuries. This article pointed out in direct terms that Ethiopia "culturally belongs to the world of the orient”, ${ }^{201}$ and was rich in orientalist descriptions and attitudes. It was in this regard not far from the other, more sound articles.

Richard Howland's 1967 mission concerning the establishment of the Ethiopian antiquities administration ${ }^{202}$ prompted him to write an article for the $\mathrm{Cou}$ rier. Howland, a US-American Art Historian, introduced his readers to the subject with the impression of a deserted, uninhabited country, building up to the sur-

197 Jules Leroy, “The Art of Ethiopia’s Painter-Scribes”, UNESCO Courier 14, no. 12 (December 1961): 30.

198 Ibid. This research perspective, however, is certainly not surprising giving Leroy's clerical provenance.

199 Several letters in: UNESCO 7 UWAS (63).

200 Otto A. Jäger, “Art of Ethiopia”, UNESCO Courier 17, no. 10 (October 1964): 23.

201 Jäger, 19.

202 See above, 2.2. 
prising, unexpected discovery of the "incredible richness of the antiquities of Ethiopia” upon his arrival. Interestingly, Howland stressed this aspect: "This is a land of contrasts, it is so highly developed as a leader in contemporary African affairs, and yet so remote and medieval and untouched in its hinterlands. The antiquities are glorious and of international significance to archaeologists and art historians, but one travels to seek them outside the capital."203 Unlike former articles, Ethiopian history was not a main focus here. Instead it centred on the value of its remains as veritable cultural heritage, living up to Western notions of the concept. Nonetheless, similar lines of argumentation reflecting the mainstream, essentialist ideas of Ethiopian Studies at that time were emphasised, although in more subtle language, speaking of "a sophisticated development that reflects Arab as well as European connexions". ${ }^{204}$ In tone the article reads like an updated variant of the adventurism of the earlier articles, in the style of travel writing, pointing out the explorative challenge of the journey to the Ethiopian antiquities, but also mentioning the nascent touristic efforts and, of course, UNESCO's efforts to unify research and preservation of heritage.

\section{Expatriate hobby-archaeologists}

Beginning in the 1950s, Ethiopia's cultural heritage, especially the sites of early Christian worship such as the rock-hewn churches of Lalibela or the Tigray rockchurches, became known to the growing number of foreign experts that came to the country as diplomats or development workers and Ethiopia gained reputation as a "happy hunting ground for amateur scholar-adventurers". ${ }^{205}$ In the same period, natural heritage also attracted interest, and Ethiopia was becoming known as a country for ornithologists and those interested in smaller rare animals. It also promised opportunities to observe nature away from the big game safaris and hunting-oriented tourism that was prevalent in other African countries. The unique landscape of the highland-plateau also attracted mountaineers and those interested in the country's geographic features. ${ }^{206}$

203 Ibid., 40.

204 Ibid.

205 David Richard Buxton, "Ethiopian Medieval Architecture: The Present State of Studies", Journal of Semitic Studies IX (1964): 239.

206 Brown, "Conservation of Nature”, 2; Ethiopian Tourist Organisation and Jill Last, Endemic Mammals of Ethiopia (Addis Ababa: Artistic Printers, 1982); Emil K. Urban, Shell Guide to Ethiopian Birds (Addis Ababa: Ethiopian Tourist Organization, 1980). 
Most of the first tourists in Ethiopia had not travelled purely for the purpose of visiting the country itself, but were there already to serve in the framework of development cooperation. These foreign experts had a decidedly practical advantage in comparison with other tourists and researchers. Outside of the capital and larger towns, mobility in Ethiopia was very limited. Though domestic flights connected the most important towns with Addis Ababa, any travel in the countryside required a four-wheel-drive with an experienced driver, or horses, mules and guides, due to the condition of the transport routes and general problems of navigation, especially during the rainy season. These circumstances rendered traveling in Ethiopia a costly and time-consuming enterprise, which required a certain flexibility in terms of schedule, and was difficult to organise from afar if one did not have local contacts. ${ }^{207}$

A particularly good example of the hobby-archaeologists' part in the production of a historical imaginary of Ethiopia is the so-called discovery of the numerous rock churches in Tigray, northern Ethiopia, through a number of foreigners during the 1950s and 1960s. These rock churches were located in a remote and secluded part of northern Ethiopia, and had supposedly existed as continuous places of worship over several centuries and contained murals as well as Christian manuscripts. Their existence had intrigued some of the international development workers who were posted to the region, and word of them quickly spread to Addis Ababa. One of these workers was Otto Jäger, who was posted on a WHO assignment in Tigray and had started exploring the churches near him. ${ }^{208}$ A story similar to that of Otto Jäger is that of Ivy Pearce, born in Great Britain and raised in New Zealand, a nurse, missionary and teacher at the Haile Selassie I University. ${ }^{209}$ During her time in Ethiopia, she travelled to the rock-churches of Tigray several times, initially inspired by Otto Jäger's reports. She organised these tours as field trips for herself and other interested foreigners. In 1972, with Otto Jäger, she published the guide book Antiquities in Northern Ethiopia. ${ }^{210}$ Ivy Pearce notably glorified the early Christian tradition and its continuous existence in her writings, stating that her own Christian belief had prompted her to spread the

207 Organised trips (like the one offered from Swan Tours, see ch. 1) were taking place but presented an exception. The number of available hotel beds and the general tourist statistics illustrate the extent of tourism: Gaidoni, "Cultural Tourism", 51-53; Ianus. Organizzazione per gli studi e le ricerche di economia applicata S. p. A., Ethiopian Tourist Development Plan, 22-24. 208 See above, he produced the UWAS Album on Ethiopian manuscript paintings.

209 Pearce, An Ethiopian Harvest, back cover.

210 Otto A. Jäger and Ivy Pearce, Antiquities of North Ethiopia: A Guide (Stuttgart; London: Brockhaus; Paul, Trench, Trubner \& Co., 1974); Ivy Pearce, “An Andrews Adventure and Pearce's Pilgrimage to the Cave and Rock Churches of Lasta”, Ethiopia Observer 12, no. 3 (1969): 142-63. 
knowledge about the rock-churches and Ethiopia in general. In terms of more official and institutional research, the "Institut" would only embark on its first scientific, systematic mission of the churches in 1970, ten years after Otto Jäger's first tour. ${ }^{211}$

At the beginning of the 1960s, barely any general introductory literature, travel writing or guidebooks on Ethiopia existed, which is why writings and reports of private travels and tours in Ethiopia were received with great interest by European publishers and magazines. ${ }^{212}$ The earliest book of this kind was the illustrated book Lalibela by Irmgard Bidder, published in 1959 and containing a report of her travel there, with numerous photographs of the rock-hewn churches, as well as her attempt at periodisation and connecting Ethiopian history within the occidental historiography. ${ }^{213}$ In her foreword, she declared her intention: "This book [...] would like to draw the reader's attention to a historical and religious centre of Ethiopia and to stimulate scientific research."214 Bidder was the wife of the German ambassador to Ethiopia and for her expedition she was able to rely on the official support of the government as well as the church. ${ }^{215}$ Like Ivy Pearce later, she was officially received by the governor of Tigray and was equipped by him with mules, guides and armed guards for the entire time of her trip. ${ }^{216}$

Between 1964 and 1967, Georg Gerster, a Swiss photographer holding a PhD in philosophy, travelled around Ethiopia and also published a book about Lalibela. The essays for his book were contributions from scientific experts, and he produced high-quality aerial photographs, publishing his images in National Geographic and other internationally acclaimed magazines. ${ }^{217}$ For Gerster, his stay in Ethiopia represented his personal "search for the holy grail", which he

211 N.N., "Une mission scientifique étudie les Eglises-Rocs du Tigre”, Ethiopie nouvelles touristiques 2, no. 7 (1973): 1.

212 R.D. Greenfield, "Ethiopian Itineraries: Some Routes in Northern Ethiopia”, Ethiopia Observer 6, no. 4 (1963): 313.

213 Irmgard Bidder, Lalibela (Köln: DuMont, 1959).

214 "Dieses Buch [...] möchte die Aufmerksamkeit der Leser auf ein historisches und religiöses Zentrum Äthiopiens lenken und die Forschung der Wissenschaftler anregen”, [translation by the author], ibid., 7.

215 Entering the churches, especially for the purpose of photographing murals and manuscripts, required not only an official permit and letter of recommendation; it depended ultimately on the final decision of the priest in charge of guarding the site. All of the books and articles discussed here give a detailed account of these difficulties.

216 Pearce, “An Andrews Adventure”; Bidder, Lalibela, 31-33.

217 Georg Gerster, “Searching out Medieval Churches in Ethiopia’s Wilds”, National Geographic 138, no. 6 (December 1970): 856-84. 
claimed to have found in the isolation and intensity of the early Christian tradition he experienced in Lalibela. Ethiopia was not Gerster's first engagement producing images for the cause of universal heritage - he had already photographed some of the most spectacular images for the Nubian Monuments Campaign. ${ }^{218}$ Gerster in fact became one of the most important producers of images for the occidental historical discourse that had evolved since the 1960s around the alleged re-discovery of Ethiopia. ${ }^{219}$

Due to their rich and unique images, these new publications were received with vivid interest by the general public and within the field of Ethiopian Studies. The detailed documentation of the churches and religious ceremonies were considered highly valuable and appreciated by researchers. The hypotheses brought forward by the lay-historians, however, faced criticism. ${ }^{220}$ Ethiopian cultural and natural heritage had by that time surpassed its existence as a niche interest known only to a few experts, and was no longer a hermetic discourse of insiders. The establishment of these broader international networks, that included but were not limited to experts and international organisations, is an important factor in the image and knowledge production that formed part of the making of Ethiopian heritage during the 1960s and 1970s.

Lavishly illustrated publications such as these allow us to trace how Ethiopia's image as the country of the "Great Tradition" gained in currency from the 1950s onward. They further show that knowledge production about Ethiopian heritage sites was not the exclusive domain of experts but, rather, was open to contributions by many other actors as well. They are a phenomenon accompanying the "boom years" of Ethiopian heritage-making in the 1960 s and "70s. International publications like coffee table books, travel guides and photo-essays mirrored each other's representation of Ethiopia as Africa's only empire. The selection of photographs and drawings as well as the canon topics centred around the narrative of the monumental remains of an advanced civilisation, the Queen of Sheba myth and the endurance of early Christian culture in an isolated location and unique natural features. This international coverage helped

218 For example the photos of the dismantling of the Nubian monuments, letter from Conrad A. Beerli to Georg Gerster, 30.9.63, in: UNESCO 069:72, A 14; Georg Gerster, "Saving the Ancient Temples at Abu Simbel”, National Geographic 129, no. 5 (May 1966): 694-742.

219 N.N., “Un imagier de l'Ethiopie: le Dr. Georg Gerster”, Ethiopie nouvelles touristiques 1, no. 10 (1972): 3.

220 Especially, Irmgard Bidder's attempt to argue for a pre-Christian origin of the churches was considered untenable. Nonetheless, the book still presented a milestone for the research on Lalibela because of its detailed photographs and drawings; Sylvia Pankhurst, "Mrs. Bidder on the Trail”, Ethiopia Observer 4, no. 7 (June 1960): 229-34. 
the promotion of Ethiopia through images of national heritage gain significant momentum.

Heritage-making in Ethiopia was a state affair, and consequently the image production was controlled through censorship, which applied to all publications and press produced and published in Ethiopia. Haile Selassie I's and Mengistu's personal support of projects involving the location of cultural heritage, and the book projects resulting from it, illustrates the decided importance of heritagemaking and the monopolisation of the related image and knowledge-production in the Ethiopian political landscape. The books of Irmgard Bidder on Lalibela or Georg Gerster on the stone churches, for example, not only make ample reference to the generous support and permission of Haile Selassie I; both books also include a personal forward by the emperor, as well as his portrait. In publications addressed to a broader Western audience, a foreword by Haile Selassie I was mandatory for an authorisation for publication by the Ethiopian government. When the UWAS Album on Ethiopian manuscript paintings was reaching its final production stages, the publisher was obliged to include a portrait and foreword of the emperor in order to receive the final permission for publication. ${ }^{221}$

This control of image and knowledge-production ensured that images of Ethiopian heritage would only circulate in a tightly determined manner and in the service of building-up an international Ethiopian national identity. In the book Churches in Rock by Georg Gerster, Haile Selassie I's words were:

Ethiopia is proud of its culture, which is without interruption from the fourth century AD to today. This is owed to the Christian faith, which victoriously withheld all influences and disturbances throughout the times and remained firmly anchored in Ethiopian culture. [...] currently foreign researchers from various countries, together with the United Nations and the Institute, are working towards conserving this heritage and finding out as much as possible about the creators of these monuments and their lifes [sic]..$^{222}$

While the conservation of heritage eventually slowed down under the socialist regime, the use of heritage as a tool of representation to produce and hold up Ethiopia's national image internationally was still relevant. The socialist government, too, commissioned Western journalists, scholars and other experts to produce coffee table books, highlighting Ethiopian heritage. Although these books did not usually include government promotion in explicit terms, the circulation of images of historical and natural wonders nevertheless promoted the country

221 Several letters concerning the finalising of the book production, in: UNESCO 7 UWAS (63). 222 Georg Gerster, Churches in Rock: Early Christian Art in Ethiopia (London: Phaidon, 1970), 1. 
in a positive way and therefore strengthened the government, particularly given the restricted access policy of the government to the heritage sites in the north, the places of main interest to foreigners. Between 1984 and 1988, the Ethiopian government under Mengistu Halie Mariam commissioned the British journalist Graham Hancock to produce a representative coffee table book and several other publications, all to promote the country in a positive way through history and culture. Hancock worked together with scholars of Ethiopian Studies on these publications, most notably with the renowned Ethiopian Studies expert Richard Pankhurst, who served as the director of Addis Ababa University's Institute of Ethiopian Studies for many years. For researching and photographing the historical sites, they were equipped with a government permit and granted special access privileges to the areas in the North, closed off due to war and conflict. ${ }^{223}$

The superlative narratives of Ethiopia peaked with the discovery of the supposedly oldest humanoid remains in 1974. Even though paleontological expeditions were conducted in Ethiopia since 1902 (Omo Valley), only in the 1960s did Ethiopian excavation sites of early human stone tools and humanoid remains gain international attention, inside the scientific community as well as from the general public. In the Omo Valley, a primary site of interest with a unique richness of geological and paleontological remains, a multidisciplinary team of French, Kenyan and US-researchers unearthed, among other things, the skeleton of Lucy, or dinknesh in Amharic, then the oldest known humanoid remains. ${ }^{224}$ Lucy and other fossils quickly served as a powerful image spreading and creating the idea of Ethiopia as the "cradle of humanity" - an image that fitted well into the existing narrative of Ethiopia as one of the oldest advanced civilisations in Africa with a supposedly unceasing legacy. In the 1984 publication Ethiopia - A Decade of Revolutionary Transformation 1974-1984, the Propaganda and Culture Committee of the Founding Congress of the Workers' Party of Ethiopia wrote the ten-year history of the new revolutionary government as a Marxist story of advancing the centuries-old struggle for total freedom from serfdom, listing achievements in education, health and mass political organisation. Preceding these praises and their statistical illustration was an eight-page introduction explaining Ethiopian ancient history and Ethiopian exceptionalism as key foundations for the revolutionary success. Ethiopia, the text explained, was naturally put in control of the surrounding regions, due to its highland-ge-

223 Graham Hancock, The Sign and the Seal: The Quest for the Lost Ark of the Covenant (London: Arrow, 2001), 8-9, 43; Hancock explicitly refers to the following book as a result of such a commission: Graham Hancock, Richard Pankhurst, and Duncan Willetts, Under Ethiopian Skies (London; Nairobi: Editions HL, 1983).

224 Derricourt, Inventing Africa, 83-84. 
ography, and was in possession of a "wealth of untapped natural resources".225 In referring to archaeological studies, the pre-historical findings and the possibility of Ethiopia as the origin of man were connected to the history of the Ethiopian civilisation, accompanied by a photograph of the Lucy-skeleton. On the following pages, photographs of well-known monuments illustrated the historical overview until the twentieth century: the Aksum obelisks, a Lalibela-church, a stela from the South of Ethiopia and the Gondar-castles.

\section{Historicising the national territory}

History and heritage were the foundations for the construction of a Pan-Ethiopian national identity, and had a special role in the transformation of Ethiopian society. The national question is seen by many as one of the core continuities along which the political revolutions and conflicts in Ethiopia during the twentieth century developed. ${ }^{226}$ Beginning under Haile Selassie I in the 1960s, the construction of national identity was a state project, employing education and historiography to graft a dominant historical narrative of an Amharic "Greater Ethiopia” onto the existing socio-political realities. To understand this, it is necessary to understand the diverse composition of the Ethiopian society as a multiethnic society populating a vast territory, stretching over different climate zones.

A good starting point to understand the complex and conflictual nature of a united Ethiopian national identity is reviewing the manifold different attempts to categorise the composition of Ethiopian society. There is no one common sense model which serves as the starting point to explain modern Ethiopia, but many individual interpretations. This is true not only of more directly political or otherwise propagandistic writings, but also in most works from the field of Ethiopian Studies. ${ }^{227}$

225 Propaganda and Culture Committee of the Founding Congress of the Workers' Party of Ethiopia \& 10th Anniversary of the Revolution, Ethiopia, 11.

226 Bahru Zewde, The Quest for Socialist Utopia: The Ethiopian Student Movement, c. 1960-1974 (Woodbridge, Suffolk; Rochester, NY: James Curry, 2014), 187-221.

227 See the overview in Teshale Tibebu, The Making of Modern Ethiopia: 1896-1974 (Lawrenceville, NJ: Red Sea Press, 1995), xxii-xxiv; most of the works cited here vary from each other in how they conceptualise the base line of distinctions in Ethiopian society, e.g. Levine, Greater Ethiopia, 29; John Markakis and Nega Ayele, Class and Revolution in Ethiopia (Nottingham: Spokesman, 1978), 21-29; Clapham, Transformation and Continuity, 20 - 26; Bahru Zewde, A History of Modern Ethiopia, 1855-1991 (Oxford; Athens, OH; Addis Ababa: James Curry; Ohio University Press; Addis Ababa University Press, 2001), 1-10; Gascon and Pourtier, La Grande Éthiopie, 204-5; Perham, The Government of Ethiopia, 49-69; Gérard Prunier and Éloi Ficquet, eds., 
As a starting point, the people living in the territorial boundaries of the Ethiopian state could be divided according to four major religious groups: Orthodox-Christian, Muslim, Falasha-Jewish and various pagan traditions. They could also be divided according to the nine major language groups: Amhara, Tigrina, Gurage, Saho, Gada, Somali, Sidama, Afar and Beja. Their classification as ethnic groups, however, leads down a slippery slope. Historically, many of today's ethnic identities cannot be traced back long before the nineteenth century, for only a few of them have a written tradition, and historical linguistic research indicates layered and complex processes of language-related identity formation. ${ }^{228}$ It is the subject of ongoing debate as to how the ethnic groups in the Horn of Africa evolved over time and along which lines they should be distinguished from one another. ${ }^{229}$ And while some works of research calculate over seventy languages, these languages often just vary to the degree of a dialect from each other. To equate spoken language with ethnicity signals a flawed reasoning. Likewise, ethnicities do not run along the geographical or geological borders, nor along administrative units. Save for Falasha-Jewish, religious affiliation is spread across the linguistic groups and the regions. Often, ethnic self-designation of certain groups varied from their political and linguistic categorisations, following a discursive dynamic rather than changes in the socio-cultural realities of a region. These categories and their delineation play a crucial role in most social and political conflicts in recent Ethiopian history, but they only make sense when read against a context of climate, geography and administrative and political boundaries.

Understanding Contemporary Ethiopia: Monarchy, Revolution and the Legacy of Meles Zenawi (London: Hurst, 2015), 17-22.

228 Wolbert Smidt, "The Tigrinnya-Speakers across the Borders", in Borders and Borderlands as Resources in the Horn of Africa, ed. Dereje Feyissa and Markus Virgil Höhne (Woodbridge: James Currey, 2010), 61-84.

229 On the problem of the political construction of ethnicities in Ethiopia see the introduction in Donald L. Donham and Wendy James, eds., The Southern Marches of Imperial Ethopia: Essays in History and Social Anthropology, 2nd ed. (Oxford; Athens, OH; Addis Ababa: James Currey; Ohio University Press; Addis Ababa University Press, 1986); and the very detailed breakdown of the proclaimed groups and identities and the subaltern position especially of the Oromo in: Éloi Ficquet and Dereje Feyissa, "Ethiopians in the Twenty-First Century: The Structure and the Transformation of the Population", in Understanding Contemporary Ethiopia: Monarchy, Revolution and the Legacy of Meles Zenawi, ed. Gérard Prunier and Éloi Ficquet (London: Hurst, 2015), 17-51. 
Some scholars have tried to understand the history of Ethiopia through the history of its natural resources and as environmental history. ${ }^{230}$ The variety of geographical and climate zones, ranging from mountainous highland regions to lowland deserts and tropical rainforests, appears to offer an obvious and more neutral feature of diversification and the opportunity to grasp the influential historical trajectories by looking at the different agricultural traditions. The Semitic highland communities in the north relied on sedentary ox-plough agriculture of grain crops, and the pastoralist, nomadic low-land communities in the south cultivated starch crops. This categorising of landscapes, too, however has quite significant socio-political implications, as this process is far from being unanimously conducted, or appreciated. ${ }^{231}$ Communities, government agencies and international experts each have varying interpretations of the existing categories, and environmental crisis and the exploitation of natural resources influence the value ascribed to different zones. ${ }^{232}$ It was within national state politics that these concepts of an environmental determination of Ethiopian society were established alongside cultural identities as defining elements for an Ethiopian historiography. ${ }^{233}$ Several competing international mapping missions during the 1960s and 1970s contributed to a database of maps on Ethiopia that has yet to be deconstructed, in order to be properly interpreted..$^{234}$ The north-south division of Ethiopia is best understood as being "not simply geographical, nor merely historical"235 and is first and foremost a helpful analytical starting point, important to understand the socio-political aspects of Ethiopian history

230 James C. McCann, People of the Plow: An Agricultural History of Ethiopia, 1800-1990 (Madison, WI: University of Wisconsin Press, 1995); James C. McCann, Green Land, Brown Land, Black Land: An Environmental History of Africa, 1800-1990 (Portsmouth, NH; Oxford: Heinemann; James Currey, 1999), 79-108; Pour une histoire environnementale de l'Éthiopie, Études rurales, 197/1 (Paris: Éditions de l'EHESS, 2016), https://doi.org/10.4000/etudesrurales.10619.

231 Very differentiated maps for climate and crop divisions are provided in Gascon and Pourtier, La Grande Éthiopie, 202, 206.

232 Bertrand Hirsch, "Une histoire de la violence”, Études rurales 197, no. 1 (2016): 173, https:// doi.org/10.4000/etudesrurales.10705.

233 Guillaume Blanc and Grégory Quenet, "Les études éthiopiennes et l'environnement”, Études rurales 197, no. 1 (2016): 17-19, https://doi.org/10.4000/etudesrurales.10638.

234 Little is known about the history of cartography in Ethiopia from 1900 on; some basic information: Wolbert Smidt, "Cartography from the 18th Century Onward”, in Encyclopaedia Aethiopica, ed. Siegbert Uhlig (Wiesbaden: Harrassowitz, 2003); Mekete Mekete Belachew, "Modern Cartography”, in Encyclopaedia Aethiopica, ed. Siegbert Uhlig (Wiesbaden: Harrassowitz, 2003); Mesfin Wolde-Mariam, "The Imperial Ethiopian Mapping and Geographical Institute", Professional Geographer 8, no. 2 (1956): 6-7, https://doi.org/10.1111/j.0033-0124.1956.082_6.x.

235 Markakis and Ayele, Class and Revolution, 21. 
in general and indispensable to understanding the history of the Ethiopian World Heritage sites in a national and local context.

The complex diversity of the Ethiopian society reflected a profound structural inequality that characterised Ethiopian society at the beginning of the 1960s. The reasons for this inequality have their roots in a number of historical-political developments. Throughout the twentieth century, the evolving hierarchy of the different social and ethnic groups in relation to the central government and to the provincial rulers can be traced in a geographical manifestation of centre-periphery or north-south inequality. ${ }^{236}$ The nation-building process in Ethiopia started at the end of the "Era of the Princes", with the re-centralisation of imperial authority under Tewodros II in 1855. Under the reign of Emperor Menelik II at the end of the nineteenth century, the territorial expansion came to a high point. Menelik II established a centralised government through imperial invasion and diplomacy, but the government failed to fully develop its capacities under his reign and was subsequently weakened in the period of Italian colonial occupation. Broadly speaking, over the course of Menelik II's twenty years of centralisation efforts, different levels of adaptation to the new bureaucratic and patrimonial imperial structures resulted in varying degrees of assimilation and integration of specific groups into the main transformation processes of Ethiopian society overall. ${ }^{237}$ While some of the provinces united under Menelik II maintained relative political power, others were completely overtaken and subject to resettlement policies. The provinces from the south in particular were forced to take in settlers from the north, and were ruled by imposed governors who were compensated for their political and land-right losses in the north by the granting of these positions. ${ }^{238}$ The varying degrees of soil-fertility in the different regions added a strong geopolitical aspect to north-south inequality. The differences in highland and lowland climate and agricultural traditions compelled the imperial regime, as well as the socialist one, to conceptualise the country's South as a resource to be exploited in order to meet the needs of the North which it supplied with food, land or labour power. ${ }^{239}$

The uneven distribution of resources was a crucial factor in terms of inequality, not only due to climatic features but also because of traditional systems of land tenure and their rapid transformation throughout the first half of the twentieth century. Exploitative sub-state level organisational structures of society had

236 Levine, Greater Ethiopia, 181.

237 And also a varying degree of integration into the leading historical narrative for the nation, Toggia, "History Writing”, 335-36.

238 Bahru Zewde, A History, 87-90.

239 Gascon and Pourtier, La Grande Éthiopie, 180-82. 
encouraged and enabled the systematic extraction of surplus value at the expense of peasants over centuries. ${ }^{240}$ Different land tenure systems had developed in the North and the South. While in both systems the right of the nobility to collect tribute - gult - existed, peasants in the North were protected through a form of private ownership, the rist system, in which land-rights were inheritable, but not sellable on the market. In the process of state modernisation and centralisation of power, gult-holders in the South were encouraged and allowed to turn their domains into private property. This effectively turned large parts of the peasant population of the southern provinces into wage workers with no rights to the land they lived on. ${ }^{241}$ This process, which had started under Haile Selassie I's government, significantly fuelled the consolidation and mobilisation of revolutionary forces from the peasants of the south during the 1974 revolution. $^{242}$ North-South inequality was a central topic in the revolutionary and post-revolutionary socialist propaganda.

Just two months after the outbreak of the revolution, the Derg implemented a rigorous land reform with the total nationalisation of all land and complete eradication of private land ownership. Although the legal situation of the southern population of tenants and landless peasants improved largely through this reform, in effect the stringent state control of agricultural production, including forced resettlement and collectivisation as well as fixed government prices, put a further strain on the rural population. The growing discontent and anxiety of the rural population, in turn, fuelled the militant oppositional upsurge starting in the north and leading to the overthrow of the Derg in $1987^{243}$

The north-south and the centre-periphery dichotomies were for a long period widely accepted among Ethiopians and foreign scholars alike. ${ }^{244}$ It does not, however, hold up to more recent analysis, which suggests viewing the periphery as a constructed political entity that would vary over time and did not constitute a homogeneous entity at any given point, nor did an idea of the "historical core zone" of the Ethiopian state. Creating a centre and a periphery began with the

240 Donald Crummey, "Banditry and Resistance: Noble and Peasant in Nineteenth-Century Ethiopia”, in Banditry, Rebellion, and Social Protest in Africa, ed. Donald Crummey (London; Portsmouth, NH: James Currey; Heinemann, 1986), 133.

241 Crummey, Donald, Land and Society in the Kingdom of Ethiopia (Urbana: University of Illinois Press, 2000), 226-260.

242 Bahru Zewde, The Quest for Socialist Utopia, 126-27.

243 Bahru Zewde, A History, 241-43; Dessalegn Rahmato also points out the disintegrating effect of the villagisation and land reform efforts under the Derg: Dessalegn Rahmato, Famine and Survival Strategies: A Case Study from Northeast Ethiopia (Uppsala: Nordiska Afrikainstitutet, 1991), 25-26.

244 Triulzi, “Battling with the Past”, 276. 
establishment of the new capital, Addis Ababa, around 1900, which sat at the conceptualised centre of the imagined totality of Ethiopian space. ${ }^{245}$ Nonetheless, it is this constructed centre-periphery and north-south divide that must be understood in order to analyse the politicisation of heritage in Ethiopia. The idea of centre and periphery, and north and south, became a central structuring principle of governance and readily lent itself to a teleology of nationbuilding, declaring it as essential for national unity that the peripheral regions orientate and subordinate themselves progressively to the national core of the central government. The historical narrative of state modernisation as a completion of the destiny of an Ethiopian national state in the territory of "Greater Ethiopia” and that had supposedly evolved naturally over centuries was one constructed along these lines, and fruitfully fed into these politics. ${ }^{246}$

\section{Heritage and the claim to Greater Ethiopia}

While competing historical narratives formed a crucial part of the revolutionary and oppositional movements in Ethiopia, they all shared a common ground in the historic anchoring of a contemporary Ethiopian society to the "Great Tradition”. In an attempt to pursue modernisation by finding a true tradition, a claim reiterated by the imperial as well as the socialist government, the Aksumite Empire was referenced as a model of success and as an anchoring point for the origin as well as the destiny and future of the Ethiopian nation in the historic discourse. ${ }^{247}$ In addition to the culturally assimilated national identity, a territorial

245 Donald L. Donham, "Old Abyssinia and the New Ethiopian Empire: Themes in Social History”, in The Southern Marches of Imperial Ethiopia: Essays in History and Social Anthropology, ed. Wendy James and Donald L. Donham, 2nd ed. (Oxford; Athens, OH; Addis Ababa: James Currey; Ohio University Press; Addis Ababa University Press, 2002), 20, 31; Alessandro Triulzi, "Nekemte and Addis Ababa: Dilemmas of Provincial Rule", in The Southern Marches of Imperial Ethiopia: Essays in History and Social Anthropology, ed. Donald L. Donham and Wendy James, 2nd ed. (Oxford; Athens, OH; Addis Ababa: James Currey; Ohio University Press; Addis Ababa University Press, 2002), 68; Christopher S. Clapham, “Controlling Space in Ethiopia”, in Remapping Ethiopia: Socialism and After, ed. Wendy James et al. (Oxford: James Currey, 2002), 11.

246 Clapham, "Controlling Space", 11.

247 This is classified as an intellectual tradition of Ethiopia which is based on importing foreign concepts as Ethiopian interpretations, resulting in using European ideas to discover a specific Ethiopian solution, and to stimulate change, Matteo Salvadore, “"Knowledge Is an Immovable Eternal Law Which Rules the World”: Gäbre-Heywät Baykädan's Blueprint for Ethiopia’s Sovereign Modernity", in Proceedings of the 16th International Conference of Ethiopian Studies, ed. Svein Ege et al., vol. 1 (Trondheim: Department of Social Anthropology, Norwegian University of Science and Technology, 2009), 131. 
unity was manifested in the claim to "Greater Ethiopia", insisting on a delineation of the Ethiopian state including Eritrea and parts of Somalia (the Ogaden).

In a way, the Derg continued these centralisation efforts in a very radical way by the means of their project of encadrement, a restructuring of the existing provinces as ethnic provinces, completely replacing the existing administrative units. This meant creating a national identity through the creation of a new spatial structure and breaking apart the power of existing ones. ${ }^{248}$

The ethnonationalism of the radicalised political movements was in opposition to the national unity of the claim to a "Greater Ethiopia", and the proponents of the various ethnonationalist movements spoke of the Ethiopian empire as an Amhara-dominated colonial enterprise. This rhetoric and approach by these various movements intensified and radicalised drastically in reaction to the authoritarianism of the Derg regime. ${ }^{249}$

Haile Selassie I attempted the project of governing a unified "Greater Ethiopia” as the leader of all ethnic groups united by the framework and the supposedly shared history of the great Ethiopian heritage. The revised constitution of 1955 consequently contained an explicit reference to this narrative and a claim to direct lineage for Haile Selassie I as a descendant of Menelik I and the Queen of Sheba- he was supposedly the two hundred and twenty-fifth descendant in this direct line. ${ }^{250}$ The exhibition of ethnicities and cultures in the museum of the Institute of Ethiopian Studies supported this colonial strategy of expressing a wide claim to territory and political power through the representation of cultures in a museum. ${ }^{251}$ Complementing these political actions, the "Greater Ethiopia” claim was rigorously transported as the ideological underpinning of national representation, with most of the image production related to Ethiopian heritage.

In 1962, the Ministry of Informationpublished a large-format brochure of one hundred and fifty pages entitled Image of Ethiopia, including colour photographs and illustrations and a comprehensive overview of all aspects of political, social and economic developments. ${ }^{252}$ Preceded by a biography of the emperor and portraits of him and the empress, the first chapter of the brochure provided

248 Clapham, "Controlling Space”, 14-24.

249 Messay Kebede, Ideology and Elite Conflicts: Autopsy of the Ethiopian Revolution (Lanham, MD: Lexington, 2011), 287-305. However, the primacy of ethnic over social and economic reasons for the insurgencies is at least questionable today and remains difficult to assess.

250 Richard Pankhurst, The Ethiopians (Oxford: Blackwell, 1998), 24; Hancock, The Sign, 24. 251 Stanislaw Chojnacki, “The Preservation of Ethiopia's Cultural Heritage (Lecture Delivered at the Meeting of the Society of Friends)” (Addis Ababa, December 18, 1969).

252 Ministry of Information, ed., Image of Ethiopia (Addis Ababa: Artistic Press, 1962). 
a four-page historical introduction. This chapter illustrates the enduring relevance and role of monumental heritage sites in the government's self-presentation and self-perception, and reveals the crafting of a ruling historical narrative: "Ethiopia, one of the oldest countries of the world and the senior independent nation of the African continent, has a long and uninterrupted history dating from before the Christian Era.[...] The Ethiopian people is of an ancient race [...] preserved through investigation and by monuments, stelae and inscriptions, in an area extending from the Red Sea Coast to the southern lakes." Starting with a paragraph on the Solomonic roots of the Ethiopian imperial dynasty, followed by just a single sentence on the " 325 recorded rulers" since then, the main consideration was given to an extended praise of Menelik II's centralisation efforts and Haile Selassie I's reforms as the main achievements in modern Ethiopian history. Such claims about recent events contrasted with photographs of the pre- and early Christian monuments in Aksum and Gondar which accompanied the text.

On the very first page upon opening the brochure, the readers were presented with an outline-map of Ethiopia, and small drawings of monuments, animals, crops and industrial and transport infrastructure strewn across the map. This type of outline-map of Ethiopia, delineating a blank territory on the inside, can be found on publications from all periods. The maps prominently featured iconic depictions of Ethiopian heritage, natural and cultural, or ethnic peoples. Most common was a map showing the "Greater Ethiopia" outline with isolated emblematic depictions of heritage and culture, such as in the pamphlet Bird's Eye View of Ethiopia published in the late 1960s by the Ethiopian Tourist Organisation (ETO), which has only the large Aksum Obelisk hovering over the otherwise blank space of the isolated Ethiopian outline map.

Outline-maps of Ethiopia were circulated widely, to a range of audiences. In the national atlas for Ethiopia, which was produced in three editions in 1962, 1981 and 1988, the numerous illustrated maps of Ethiopia did not include neighbouring territories, with the state boundaries surrounded by the white background of the pages. This establishment of a national geo-body as a demonstration of national sovereignty over a certain territory and people served to delineate the imagined community. ${ }^{253}$ On brochures and government publications, currency, stamps and letterheads, the Ethiopian geo-body was the logo

253 Jordana Dym, "Democratizing the Map: The Geo-Body and National Cartography in Guatemala, 1821-2010", in Decolonizing the Map: Cartography from Colony to Nation, ed. James R. Akerman (Chicago: Chicago University Press, 2017), 163 shows this for Guatemala. 


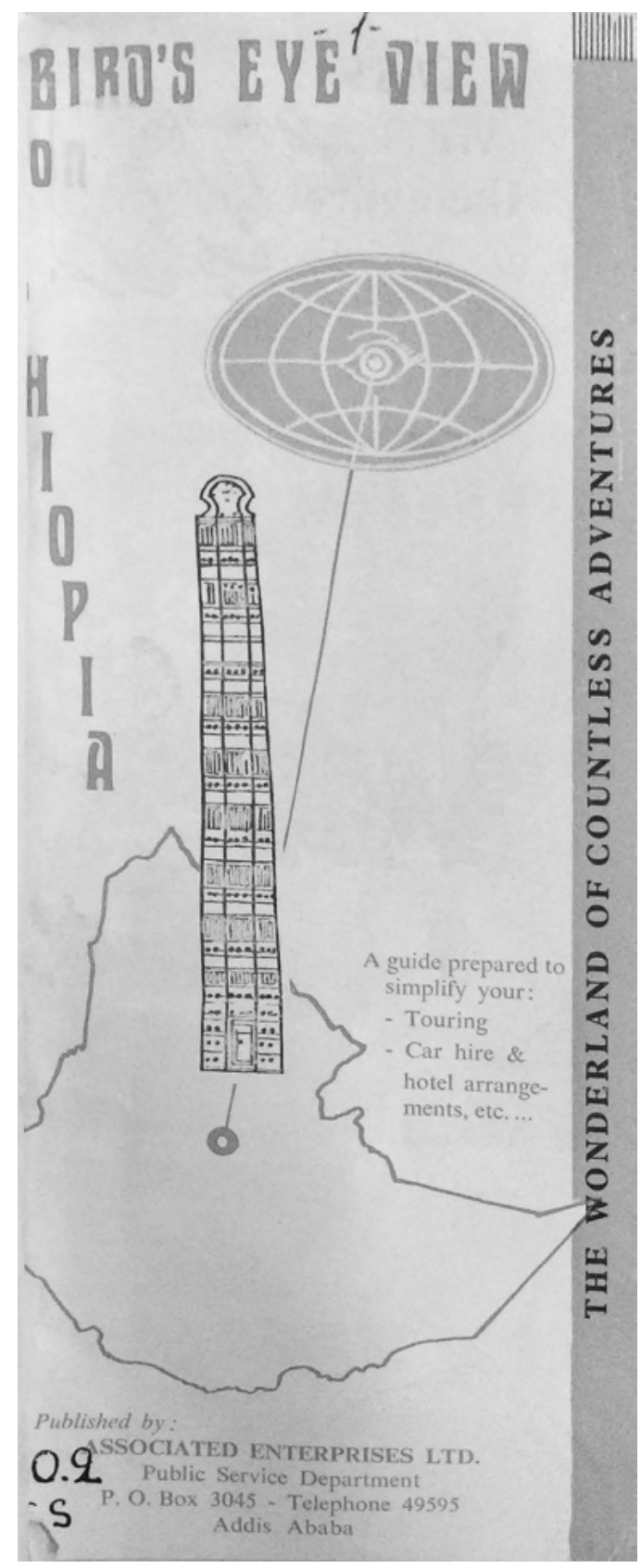

Figure 4: Cover image, Bird's Eye View of Ethiopia, Associated Enterprises Ltd. Addis Ababa, n.y. 
of the Ethiopian nation and, together with the iconic drawings of monuments and natural features, became part of a lasting national inventory. ${ }^{254}$

The representation of Ethiopian heritage sites on these outline maps conceptually defined, located and evenly distributed patrimonial resources across the national landscape. ${ }^{255}$ The Greater Ethiopia on these maps was presented as the national territory, filled with a collage of icons of heritage and culture, leaving no blank space in-between, such as in the 1976 Tourism Review. ${ }^{256}$ On the cover, which states in both English and Amharic the title of the brochure as well as the fact that it is published by the Ethiopian Tourism and Hotel Commission, watercolour paintings of ancient monuments, modern churches, the modern town hall of Addis Ababa, wildlife and scenes of rural and religious life are merged into a colourful array within the outline of Ethiopia, surrounded by the completely blank and monochrome territories of the neighbouring states.

On the cover of the 1989 publication of the Ethiopian Ministry of Information Ethiopia: A Cradle of History are drawings of the main monuments of the World Heritage sites in Aksum, Gondar, Lalibela, Harar and the pre-historic site of Sidamo, placed within an outline map which is transparent and layered over a panoramic photo of the Ethiopian highlands, filling the entire page as a background image on the cover. This book brought together an essay on the historic development of Ethiopia and a selection of maps illustrating the history of the Ethiopian state. The actual language of the text and the visual language of the maps suggested Ethiopian state history as the centre of regional development, and a continuous, consequent outwards expansion of the Ethiopian empire throughout the past centuries.

\section{Heritage and territorial conflicts in the Horn of Africa}

The claim to power of the central Ethiopian government of the pre- and post-revolutionary period was not only contested internally, but more critically in the direct regional surroundings. Ethiopia's territorial demands were legitimised, from the official Ethiopian viewpoint, by the historical tradition that was claimed as

254 Sarah A. Radcliffe, "National Maps, Digitalisation and Neoliberal Cartographies: Transforming Nation-State Practices and Symbols in Postcolonial Ecuador”, Transactions of the Institute of British Geographers, New Series 34, no. 4 (2009): 429 shows this for Ecuador.

255 The concept of the "patrimonial resource" is borrowed here from Lisa Breglia, who made similar findings in Mexico: Breglia, Monumental Ambivalence, 30.

256 Ethiopian Tourism \& Hotel Commission, ed., Ma-hdara turizem / Tourism review (Addis Ababa: Tourism Promotion Department of the Ethiopian Tourism \& Hotel Commission, 1979). 


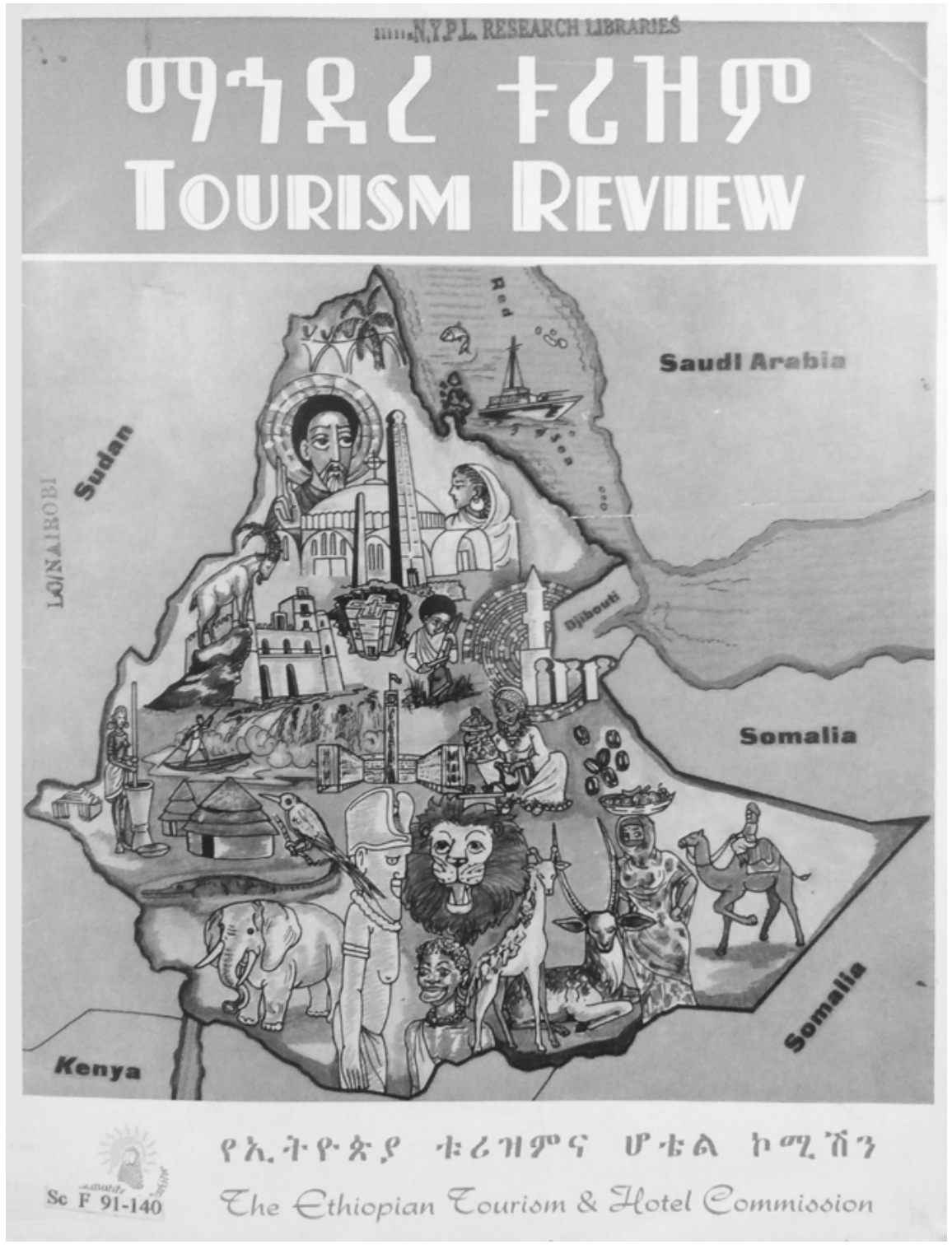

Figure 5: Ethiopian Tourism \& Hotel Commission, ed. 1979. Ma-hdara turizem / Tourism review. Addis Ababa: Tourism Promotion Department of the Ethiopian Tourism \& Hotel Commission. 


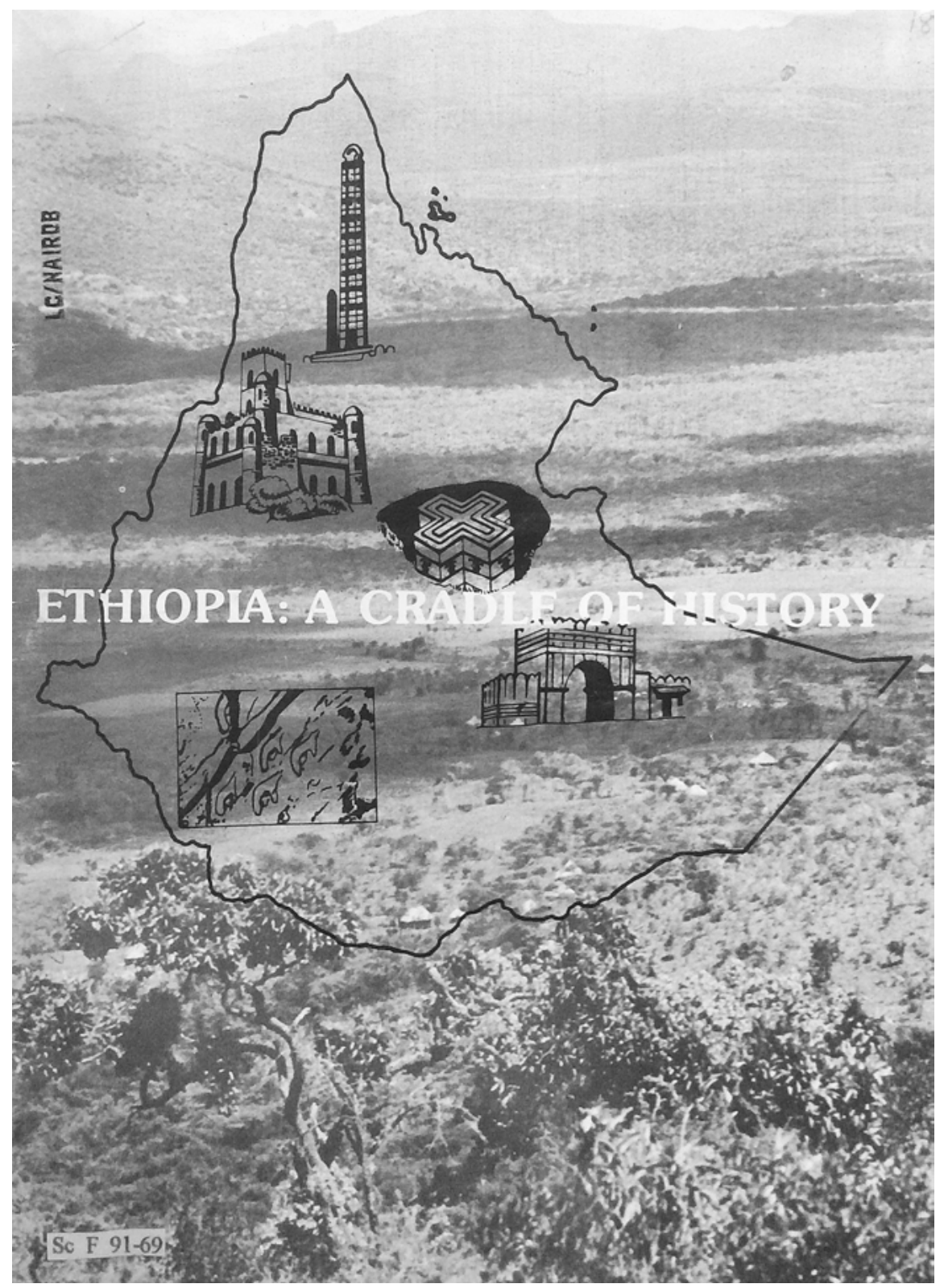

Figure 6: Ethiopia, ed. 1989. Ethiopia: A Cradle of History. Addis Ababa: Ministry of Information, Department of Press. 
national history. Heritage and the establishment of historic claims formed part of a political strategy, also in regards to the conflicts at the disputed margins of the "Greater Ethiopian" state territory.

International relations were an external factor in the formation of an Ethiopian national state after the end of the Italian occupation in 1941. The recognition and validation of Ethiopian state boundaries by other state powers was a result of diplomatic efforts, and in a time that notably fostered the principle of building the international system as one between sovereign governments, this helped greatly to establish the central government's power over Ethiopian territory. $^{257}$

Ethiopia was at the heart of several conflicts in the Horn of Africa. As a legacy of arbitrarily drawn colonial borders, the Horn of Africa, until today, is one of the most conflict-ridden regions of the world, and borders and borderlands, questions of nationalism and identities, and land claims as well as cross-border movements are at the centre of these conflicts. Ethiopia's disputed south-eastern border with Somalia was the cause of the particularly violent Ogaden War in 1977, which prompted international involvement and, although ending in 1978, did not immediately succeed in establishing a peaceful situation in the Ogaden region, which was still claimed by Somalia until 1980. In the north of Ethiopia, the conflict with Eritrea had been brooding ever since the annexation of the former federal state of Eritrea into the Ethiopian empire, and throughout the entire period of the Derg regime until Eritrean independence in 1990. Especially the last of these two conflicts fuelled the internal ethno-liberation movements and their provocation of armed conflict, putting many regions of Ethiopia into the shadow of armed conflict for many decades. 258

Ethiopia's claim to a regional hegemonic position was strongly tied to the historic narratives of a Greater Ethiopia and instrumentalised to justify the denunciation of federalism, nationalist movements and the territorial claims of Somalia. Thus, the territorial conflicts and the necessary foreign regional positioning of Ethiopia also perpetuated the establishment of historical narratives of Ethiopian hegemony. The image of Ethiopia, constructed with the aid of an internationally acclaimed national heritage, also has to be interpreted in this context. The "Greater Ethiopia" maps shown above illustrate this image construction, as they simply extended, as if naturally, over disputed territories. An outline-map, including Eritrea and the Ogaden as part of "Greater Ethiopia”, published during these conflicts, certainly had an impact beyond the tourism marketing sphere.

257 Clapham, “Controlling Space”, 11.

258 Dereje Feyissa and Hoehne, "One State Borders”, 4-6. 
There is another aspect that suggests that for Haile Selassie I establishing heritage was part of a larger political strategy to sustain the state centralisation and consolidation process. International relations were a highly relevant factor in the formation of the Ethiopian national state. The recognition and validation of Ethiopian state boundaries by the larger international powers, during a period where the international system was being built as a system between sovereign national governments, greatly contributed to strengthening the central government's grip on the country's provinces.

\section{Monopolising heritage-making through cultural assimilation}

In the political construction of an Ethiopian national identity, the affiliation and streamlining of cultural identities was a crucial factor, and in order to monopolise heritage-making as a state affair, a politics of cultural assimilation and censored historiography was institutionalised. All historic research and historic mediations, such as history schoolbooks and museum exhibitions, were highly censored and adapted according to the political programme. Claiming the relevant existing heritage sites as national heritage, in particular the cultural heritage sites of the historic north, so as to furnish the "Great Tradition" narrative, was a strategy to stabilise the central government's power, both imperial and socialist. This dominant narrative was built not only on praising the dynastic success, but also on a systematic silencing and devaluing of non-Christian and nonAmharic groups, such as the Oromo, who were often portrayed as detrimental to the development and culture of the Ethiopian empire in mainstream historiography by both Western and Ethiopian scholars. ${ }^{259}$

Haile Selassie I had introduced a revised constitution in 1955, which, as a part of this stabilising strategy, aimed to achieve national identity by imposing cultural assimilation on the provinces. With the revised constitution, Amharic was declared as the official language of Ethiopia, even though only $25 \%$ of the population were native speakers. ${ }^{260}$ The prioritising of Amharic as the lingua franca for the Ethiopian national state reinforced a cultural assimilation strategy that built on the Abyssinian narrative, essentially arguing that the imperial heritage of Axum, Lalibela and Gondar alone had reached "a standard of cultural development and progress comparable to any attained by any other country in

259 Hussein, "The Subtle Connection”, 64-65.

260 Balsvik, Haile Selassie's Students, 10; Paulos Milkias, Haile Selassie, Western Education, and Political Revolution in Ethiopia (Youngstown, NY: Cambria, 2006), 53-58. 
the civilised world."261 The Amharic and Semitic cultures purportedly provided the only valid historical legacy and heritage of Ethiopia, usurping all other narratives in the official representation. In the historiography, non-Christian groups were rendered into a bulk of "Jewish, Arabic and [...] Nubian immigrants"262 and sidelined into a negligible influence at the margins of the Axumite empire.

An element of revolutionary propaganda was devoted to denouncing Haile Selassie's cultural assimilation politics as part of "feudal" imperial politics. Consequently, the Derg claimed to disregard the cultural assimilation policy and to strengthen the autonomy of different ethnic groups within the Ethiopian national state. Religious and language diversification were installed as official institutions after 1974, to demonstrate that the equality of all cultures and nations within the great Ethiopian nation had been achieved through the socialist government. Yet, this official promotion of the "self-determination of cultures" was executed under the leadership of the central government. This supposedly empowering and radical political claim left no doubt that the self-determination was nevertheless to be strictly confined to remain within the defined boundaries and authority of the Ethiopian national state. Mengistu Haile Mariam's call for "unity or death" for the Ethiopian people served as a propaganda slogan to some and as a threat to many others. ${ }^{263}$

Religious identity played a crucial part in the consolidation of the new national identity. Haile Selassie I's achievement of the re-nationalisation of the Ethiopian Orthodox church increased his popular success and at the same time his position over the church. The reinstalling of an Ethiopian Patriarch as head of the church, as opposed to the then-existing tradition of an Egyptian one, further supported his centralisation efforts, as the church became more dependent on the state and the distributed monastic institutions became weaker. Historically, the Orthodox church had been an important landowner in the centralised feudal system, collecting taxes and overseeing education as well as health services in many areas. Under Haile Selassie I, these functions were transferred to the government and the church was given the role of an "ideologue" within the imperial government, "providing moral and divine legitimisation of the Solomonic dynasty and imperial dominance."264 After the 1974 revolution,

261 Ministry of Information, Ethiopia, Past and Present, 11.

262 Ibid., 10.

263 John Markakis, National and Class Conflict in the Horn of Africa (Cambridge: Cambridge University Press, 1987), 245.

264 Kostas Loukeris, "Church and Attempted Modernization in Ethiopia”, in Ethiopia in Broader Perspective: Papers of the XIIIth International Conference of Ethiopian Studies, Kyoto, 12-17 
all church property was seized and nationalised, and was, according to the socialist orientation, written out of national identity. ${ }^{265}$ From 1980 onwards, religion was once again officially endorsed as part of the Ethiopian national identity, to gain popular support, and to establish and strengthen the identity of peaceful religious coexistence in Ethiopia and the existence of a successfully multi-ethnic state. ${ }^{266}$

From 1950, historiography was installed systematically in the nascent academic landscape, when a number of Ethiopian historians were sent to be trained in Western academic institutions in order to produce a version of Ethiopian history that could be made to compete with Western history and integrate with it. Ethiopian and non-Ethiopian historians alike "did not question the "Great Tradition" of a centralising, independent and unitary State rooted in an ancient past and led by an innovative monarchy". ${ }^{267}$ In effect, Ethiopian historiography, even as it became an academic discipline in the 1950s, did not happen autonomously, but in the service of the national state, and largely relied on existing cultural and ideological constructs as opposed to being an investigative, empirical field. And this was the case for Ethiopian historians and foreign historians of Ethiopian history alike. ${ }^{268}$ Shortly after the first cohort of students had graduated from Haile Selassie I University, they radicalised the discourses of national identity, history and heritage, calling for a quest for a "true Ethiopian" way, attempting to graft Western principles, liberal values and modernisation onto the existing "distant past" and "Great Tradition" narratives assumed by the government. ${ }^{269}$

Through the de facto assimilation of all cultural identities into the Amharic, Christian, north-Ethiopian cultural identity, the dominant narrative of the national identity was set and so were the representative uses of heritage and the heritage sites. The most effective institutions for enacting this linguistic and historical politics were those of education and the military. ${ }^{270}$ Ethiopian society traditionally lacked a middle class, a fact seen by many as an impediment to modernisation and progress. The military was the only available path for class

December 1997, ed. Katsuyoshi Fukui, Eisei Kurimoto, and Masayoshi Shigeta, vol. 2 (Kyoto: Shokado Book Sellers, 1997), 214-15.

265 Stéphane Ancel and Éloi Ficquet, "The Ethiopian Orthodox Tewahedo Church (EOTC) and the Challenge of Modernity”, in Understanding Contemporary Ethiopia: Monarchy, Revolution and the Legacy of Meles Zenawi, ed. Gérard Prunier and Éloi Ficquet (London: Hurst, 2015), 76-80.

266 Loukeris, "Church and Attempted Modernization in Ethiopia”, 216.

267 Triulzi, "Battling with the Past”, 278.

268 Ibid., 276-78.

269 Milkias, Haile Selassie, 79-100.

270 Bahru Zewde, The Quest for Socialist Utopia, 193. 
mobility, and by imposing Amharic as the only language for the military, Amharisation gained significant momentum under Haile Selassie I. ${ }^{271}$ After the revolution, the new government was formed of leading actors from the military, in effect putting the socialist government into the hands of the newly Amharised elites. $^{272}$

Haile Selassie I had put an emphasis on developing secondary and higher education. After the revolution the official policy shifted towards prioritising alphabetisation of the masses over higher education. This resulted in an steep increase in primary education, with an emphasis on quantity of access and largest possible regional coverage. In the zemecha development campaign, all students enrolled in secondary schools and university were dispatched on a mandatory teaching mission into the rural areas of Ethiopia, so as to enforce revolutionary politics despite the lack of administrative capacities of the Derg. ${ }^{273}$ This strategy aimed at producing a high basic functional literacy among the population rather than competitively educated candidates suitable for more specialised and advanced training. In this process, a different kind of cultural dominance was introduced through the Amharisation of secondary school education, resulting in a decline of English-speaking students. Consequently, the rising number of high school graduates did not translate into a larger number of students qualified to enter university, as higher education still largely happened in English. This meant that socialist education policies led to a generational rift between an educated elite, who had benefited from the imperial educational system, and the following generation of more basically-educated Ethiopians. This educated elite formed a crucial part of the leadership level in post-revolutionary Ethiopia. ${ }^{274}$

The institutional knowledge production happened intertwined with political turmoil and change. On the one hand, the discourse of national identity during and after the revolution also consisted of revealing the decadence and malfunction in the recent empire. However, while the imperial state was critically attacked for its feudalistic traits, and held responsible for the inequality in Ethiopia, the socialist government also relied on a version of the historically rooted, unitary state in need of strong central leadership. In this logic they linked them-

271 Salvadore, “Knowledge”, 129.

272 Levine, Greater Ethiopia, 185-90; Jacob Wiebel, “”Let the Red Terror Intensify”: Political Violence, Governance and Society in Urban Ethiopia, 1976-78”, International Journal of African Historical Studies 48, no. 1 (2015): 17; Gérard Prunier, "The Ethiopian Revolution and the Derg Regime", in Understanding Contemporary Ethiopia: Monarchy, Revolution and the Legacy of Meles Zenawi, ed. Gérard Prunier and Éloi Ficquet (London: Hurst, 2015), 217-19.

273 Clapham, "Controlling Space”, 15-16.

274 Clapham, Transformation and Continuity, 150 - 52. 
selves back to a tradition of the "people of Ethiopia" that had to be freed from the chains of feudal repression by the socialist revolution, and brought to their true calling. A key argument of the student movements that transcended revolutionary propaganda into that of the socialist government after the revolution was to frame the Ethiopian imperial times as feudalistic, exploitative and "blood-thirsty", having spoiled the country's great past. ${ }^{275}$ More specifically, the government pledged to make monuments and national heritage accessible to the masses, to educate everyone about the "Great tradition" of Ethiopia to help with the socialist endeavour, and declared the preservation of cultural heritage as part of the zemecha development campaign. ${ }^{276}$

After the 1974 revolution the conservation of natural heritage and wildlife, too, was framed as an act of revolutionary liberation. In the official newspaper Ethiopian Herald, a regular series of articles was published to educate the Ethiopian public about the Ethiopian heritage and the necessity to preserve "the progressive cultural heritages of the past" ${ }^{277}$ to advance the socialist revolution and reconstruction of society. The 1978 brochure Wildlife Conservation in Socialist Ethiopia presents a good example:

\begin{abstract}
This ancient heritage of forests and wildlife is one of the precious natural resources of Ethiopia. But over the centuries the feudal overlords, straddling the back of the country, exploited these resources and very tragically depleted them. The vast areas of land, denuded of the giant trees once that covered it, bear silent testimony to this mindless cruel destruction. [...] The feudal regime had, only of lately, made some faint attempts at conserving these wildlife resources and the forest. Still the destruction continued. But with the onset of the popular revolution in Ethiopia in 1974 which overthrew the feudal regime, conservation has gained momentum and has become a massive force. From the very beginning of the revolution, the PMAC [Provisional Military Administrative Council] declared total conservation of the wildlife and forest resources of Ethiopia as a part of its avowed policy. ${ }^{278}$
\end{abstract}

In contrast to these images of heritage and national identity, throughout the 1960s and 1970s, official politics had to compete with a lively intellectual tradition and political discourse. Opposition groups and movements made the case

275 Bahru Zewde, The Quest for Socialist Utopia, 39.

276 Statistics on Cultural Development in Ethiopia, February 1975 in: ARCCH, 14-1, Folder 5; Ayalew Sisay, Historical Development, 162-63.

277 “Cultural Revolution, Cultural Heritage”, The Ethiopian Herald, 27.12.1978; similar articles, all in The Ethiopian Herald, include: "Socialist Society, Cultural Progress", 20.12.1978; "Preserving Nations” Relics', 5.2.1980; “Africa in Antiquity”, 4.8.79; "Prelude to Party Formation - Care for Nation's Resources and Heritage”, 25.12.82.

278 Forestry and Wildlife Conservation Development Authority, Wildlife Conservation in Socialist Ethiopia (Addis Ababa: Forestry and Wildlife Conservation Development Authority, 1978), 4. 
for or against assimilation and the historic identities of the major (ethnic) groups were discussed in a nuanced, yet agitated and propagandistic manner. The distinct Marxist and nationalist orientation of the student movement formed the ideological basis for radicalisation and mass-mobilisation leading up to the revolution. Consequently, the aggressive use of historic narratives and heritage as a weapon in the revolution and the subsequent years influenced the political dimension of national heritage. The Ethiopian student movement applied Marxist concepts of feudalism and imperialism and the official historic narratives of empire were turned against the government in many of the student writings, justifying its overthrow. This confrontation of traditional power structures with modern theory has to be read against a transnational process, and can be compared to campaigns in other African countries, such as the demystification campaign of Guinea's Sekou Touré, during which traditional religious and political practices of secrecy and fetishes were publicly revealed as an act of modernisation and liberation. ${ }^{279}$ Denouncing the "Great Tradition" was a key slogan of the student movement, calling instead for the creation of a state "in which all nationalities participate equally in state affairs". In one of its most influential chants, the student movement proclaimed the goal that no longer "to be an Ethiopian, you will have to wear an Amhara mask [...]". ${ }^{280}$ Slogans like this were responsible for the successful mass mobilisation of marginalised ethnic/regional identities in the protests.

Contrasting interpretations of history and claims to heritage resulted, during the course of the student movements, not only in a revolutionary propaganda that would then reach further into the post-revolutionary government, but also in feeding the theoretical background and ideological foundation of the various national liberation fronts. ${ }^{281}$ The revolution had actualised the question of national identity and with the dimension of cultural identity had thus turned the question of national heritage and historic narratives into a cultural conflict. Heritage, once more, was only represented by the "Historic North" sites and the ruling elites of the Ethiopian state. The ethnic national movements rejected the concept of an Ethiopian empire as a succession to the great, classical tradition that was simply spoiled by imperial feudalism and had to be freed by revolutionary forces. In fact, the post-1974 regime was confronted by renewed accusations that

279 Bahru Zewde, The Quest for Socialist Utopia, 129-30; Mike McGovern, Unmasking the State: Making Guinea Modern (Chicago: The University of Chicago Press, 2013).

280 Walleligne Mekonnen, "On the Question of Nationalities in Ethiopia”, quoted in: Balsvik, Haile Selassie's Students, 277; Marzagora, "History”, 12-13.

281 Bahru Zewde, The Quest for Socialist Utopia, 258. 
it continued the empire in a different guise and suppressed the distinct ethnic identities.

The Tigrayan People's Liberation Front in particular built their insurgency on this argument and refused to let the Tigrayan heritage-after all, save for the two paleontological sites in the deserts of the Lower Valley of the Omo and the Awash, all Ethiopian World Heritage sites were located in Tigray-be affiliated with the official promoted Amhara-centric Ethiopian identity. Similarly, the Eritrean People's Liberation Front, as well as the Oromo and Western Somali Liberation Front, raised the accusation of colonial continuity by the Ethiopian socialist regime of the Derg, directly linking it to the expansionist tendencies of Menelik II and Haile Selassie I, and declaring it an "act of internal colonialism". ${ }^{282}$ Throughout all the social changes and transformative processes of the revolutionary decade $1970-1980$, history and heritage as a spatial and symbolic representation became a crucial tool in the political opposition for marginalised groups, basically deriving a contrary version, one that rendered the "good empire" into the "bad empire". In this climate the quest to legitimise the political present through the past became a contested territory, and the imperial state, the revolutionary groups and forces as well as the socialist government each had to make it a priority to monopolise the establishment and representation of heritage.

Yet, despite the strong oppositional voices among intellectuals-especially those of the diaspora-heritage-making in terms of officially labelled national sites remained a state monopoly, and thus a strategy exclusively available to those holding government power. From an analytical viewpoint, the construction and self-designation of ethnic identities of Tigrayans, Oromos, Eritreans, Ethiopians, Amharas and others has in itself to be seen as a set of discourses monopolising the dimension of political conflict for the constitution of these ethnic identities. In the context of the revolution, regionalist demands and historiographies attached in the service of them, and the revisionism of exiled Ethiopians, transformed the field of Ethiopian historiography into a minefield, on which it became ever more difficult to practice balanced research that was impervious to instrumentalisation. ${ }^{283}$

The cultural assimilation and establishment of a dominant historic narrative and selection of heritage sites became a mirror for the social inequalities prevailing and fuelling the civil conflicts of the 1960s and 1970s. Essentially, Ethiopian

282 Marzagora, "History", 21.

283 Triulzi, "Battling with the Past”, 279; this is also clear from the works of Western scholars at this time, e.g. Levine, Greater Ethiopia; Markakis and Ayele, Class and Revolution; Graham Hancock explicitly mentions his relations with the Derg in Hancock, The Sign, 8-9, 43. 
history, in the "Greater Ethiopia” narrative, remained, like many European histories, a history of the upper class or of the elites, not the peasants who composed the large majority of the population. This focus of attention on the monuments of antiquity and the medieval period reinforced the idea that Ethiopia's history and heritage was to be found in the northern highlands. This left aside the larger part of the country, rendering more than half of it into an "Ethiopia without monuments", marginalised in the narrative of national representation. As with the monuments, historically significant processes, such as the revolutionary years, were exclusively located in and associated with the north. ${ }^{284}$

Because of the revolutionary decade of the 1970s and regional conflicts in the Horn of Africa, Ethiopian nation-building cannot be clearly understood as a continuous process. Despite the ruptures caused by the revolution, however, Ethiopian history throughout the twentieth century can be viewed in light of a continuous process of power centralisation. The politicisation of heritage is best interpreted along these trajectories of centralisation and nationalism. The establishment of national heritage in Ethiopia, and the underlying question of national identity, were rooted in the changing dynamics of competition for authority, territory and resources outlined above. In territorial conflicts, claims were made on the basis of historical narratives and heritage.

In the most recent scholarship of Ethiopian historians, many authors define Haile Selassie I's and Mengistu Haile Mariam's politics as internal colonisation. Often, the view that even with the ideological shift of the 1974 revolution the pattern of hierarchy and centre-periphery relations remained unchanged is the introductory assertion for a study of the political systems and social history of marginalised regions and ethnicities, such as Abbas H. Gnamo's study on the ArsiOromo, or Temesgen Baye's work on Muslims in Ethiopia. ${ }^{285}$ Without lending oneself to the particular historiography of any of the distinct national identities in Ethiopia, understanding Ethiopian national history in the twentieth century as imperial history opens up the possibility of interpreting the use of heritage and national parks as a powerful political tool.

284 Gascon and Pourtier, La Grande Éthiopie, 13-16.

285 Abbas H Gnamo, Conquest and Resistance in the Ethiopian Empire: 1880-1974; the Case of the Arsi Oromo / by Abbas H. Gnamo, African Social Studies Series BV013510202 32 (Leiden [u.a.], 2014); Temesgen Gebeyehu Baye, "Muslims in Ethiopia: History and Identity", African Studies 77, no. 3 (July 3, 2018): 412-27, https://doi.org/10.1080/00020184.2018.1475634; see also: Jeylan Hussein, "Taking Narratives on Identity-Based Conflicts in the Horn of Africa Seriously: The Case of Intergroup Conflicts at Pastoral Frontiers in Ethiopia”, International Journal of Peace Studies 21, no. 1 (2016): 1. 